\author{
Review Article
}

\title{
A CRITICAL EVALUATION ON AKALA PALITAM
}

\section{Anupriya P.S ${ }^{*}$, Arun Pratap ${ }^{2}$, Lekshmi R ${ }^{3}$, Arjun Chand C P4}

*1PG Scholar, ${ }^{2}$ Professor \& HOD, ${ }^{3}$ Assistant Professor, ${ }^{4}$ Associate Professor, Department of Kayachikitsa, Pankajakasthuri Ayurveda Medical College \& PG Centre, Kattakkada, Thiruvananthapuram, Kerala, India.

\begin{tabular}{l}
\hline Article info \\
\hline Article History: \\
Received: 18-10-2021 \\
Revised: 22-11-2021 \\
Accepted: 08-12-2021 \\
\hline KEYWORDS: \\
Akala Palitam, \\
Premature graying, \\
Vivarna Kesha, \\
Bhrajaka Pitta, \\
Melanin.
\end{tabular}

ABSTRACT

Hair color reflects the health of an individual and the discolored hair indicates the pathological state. Palitam is a physiological process when it occurring in old age. Whereas Akala Palitam (premature graying) is a pathological condition manifests in early stages of life. It is characterized by Vivarna Kesha (discolored hair) along with altered hair texture and the predominant Dosha attributes Vivarnata to Kesha.

Hair color is determined by a pigment called melanin (relative proportions of eumelanins and phaeomelanins) in hair follicles. Diffuse loss of hair melanin during early stages of liferesults in premature graying. In Ayurveda, Bhrajaka Pitta, one among the five types of Pitta located in skin is responsible for the attribution of hair colour. Thus it performs the function similar to melanin pigment in hair follicles. When there is Pitta dosha Vridhi in Rasadhatu along with vitiation of other two Doshas it leads to manifestation of Vivarna Kesha with altered hair texture thus results in Akala Palitam. It is a type of Raspradoshajavikara in which the signs and symptoms varies based on the predominant Dosha. Treatment option for Akala Palitam is also specific based on predominant Dosha. So a critical evaluation on Akala Palitam is essential to understand the etio-pathogenesis of the disease for its better management.

\section{INTRODUCTION}

Hair colour has a striking role in human characteristics. According to Acharya Charaka, Krishna Varna Kesha (black coloured hair) seen in child isconsidered as a characteristic feature indicative of long life span.[1] Thus hair colour suggests the health of an individual. As age advances hair turns to gray naturally whereas premature graying in early stages of life is pathological. Premature graying is defined as the onset of graying of hair before the age of 20 years in Caucasians and before 30 years in Africans.[2] Definition of premature graying with respect to the Asian population is lacking. ${ }^{[2]}$

\begin{tabular}{|l|l|}
\hline \multicolumn{3}{|c|}{ Access this article online } \\
\hline Quick Response Code & \\
\hline
\end{tabular}

A recent study reported that $6-23 \%$ of people develop $50 \%$ of gray hair by 50 years of age.[3]

In Ayurveda, Palitam (graying) which occurs in early stages of life can be termed as Akala Palitam (premature graying). It is a pathological condition where discolouration of hair is attributed by the predominant Dosha. A critical evaluation on Akala Palitam helps to understand its etio-pathogenesis and treatment.

\section{Relation Between Akala Palitam and Premature Graying}

Akala Palitam is a Shirokapalagata Roga, in which hair colour as well as texture of hair get impaired. The discolouration of hair depends upon the predominant Dosha (Vata, Pitta, Kapha). Thus Vata, Pitta, and Kapha Dosha results in Shyava (bluish black), Peeta (yellowish) and Shukla (whitish) Varna (colour) of hair respectively.

In humans, hair colour is determined by the relative proportions of two forms of melanin pigments such as eumelanins (brown-black) and phaeomelanins (yellow-red).[4] It is formed by the melanocytes situated in the hair bulb epithelium around the upper half of the dermal papilla amongst cells destined to 
form hair cortex. When there is diffuse loss of melanin due to reduction in the activity of melanocytes in early stages of life, it leads to premature graying.

Among Tridoshas, Pitta dosha having predominance of Agni Mahabhoota, plays an important role in production of complexion. Bhrajaka Pitta (one among the five types of Pitta) located in the skin imparts and maintain the normal skin color. ${ }^{[5]}$ It is also responsible for hair color because the hair arises from the Romakoopa (hair follicle) located in the skin. Thus Bhrajaka Pitta residing in the Shirogata Twak has the function similar to melanin in hair follicles. When there is vitiation of Bhrajaka Pitta it causes Pachana of Kesha and produces discoloration of hair in association with other two Doshas. So in premature graying, vitiation of Pitta Dosha associated with vitiation of other two Doshas can be seen.

\section{Nidana (Etiology)}

The causative factors include Aharaja (dietary factors), Viharaja (regimens) and Manasika (psychological factors) Nidanas (causative factors) which primarily vitiates Pitta Dosha in association with Vata Dosha and Kapha Dosha. Similarly the etiological factors of premature graying include altered metabolism, nutritional deficiency, psychological stress, genetic factors etc., but the exact etiopathogenesis is unknown.

Akala Palitam is enlisted under Rasapradoshajavikara, so Nidana causing Pitta dosha vridhi in Rasadhatu results altered Dhatuparinama and leads to Akala Palitam. Similarly altered metabolism due to thyroid dysfunction can hamper melanogenesis and leads to premature graying.

Aharaja Nidanas includes excessive consumption of food having Katu Rasa (pungent taste), Amla Rasa (sour taste), and Lavana Rasa (salt taste), Food having Teekshna (sharp), Ushna (hot) and Vidahi (cause burning) properties. Excessive use of Katu Rasa produces Shareeratapa (body heat), Amla Rasa results in Vilayana of Kapha Dosha (liquefaction of Kapha) and Lavana Rasa causes vitiation of Pitta as well as heating sensation in the body. Teekshna (sharp), Ushna (hot) and Vidahi (cause burning) properties increases the Pitta Dosha. There are studies showing that drinking alcohol impairs the absorption of vitamin B-12 and thus leads to premature graying as it is essential to maintain good skin and hair. Madya increases Pittadosha by its Teekshna and Ushna Guna. Excess intake of salt results in premature graying by increasing the risk of free radicals in the body, it causes oxidative stress and the failure of antioxidant effect could damage melanocytes leading to decreased pigmentation.

Viharaja Nidanas include excess indulgence in Ayasa (physical exertion), Upavasa (fasting) which results in vitiation of Pittapradhana Tridosha. Also following sedentary lifestyle can results in Rasadhatu Dushti and leads to Akala Palitam.

Manasika Nidanas (psychological stress) such as Krodha (anger), Shoka (sadness) and Shrama (mental exertion) causes Pittapradhana Tridoshakopa and result in increased Sareera Ushma (body heat). These Manasika factors are specifically mentioned while describing the pathogenesis of Akala Palitam. ${ }^{6]}$ In the manifestation of premature graying psychological stress plays a major role as it results oxidative stress.

Akala Palitam can even manifest as Janmabalapravritta Vyadhi (diseases occurring in children due to improper dietetics and lifestyle followed by mother during pregnancy). If a women during pregnancy consume Lavana Rasa in excess it leads to manifestation of Akala Palitam in offspring. ${ }^{[7]}$ It is also commonly seen in Pitta prakruti persons. Similarly premature graying can even manifest due to genetic factors.

\section{Samprapti (Etio-pathogenesis)}

Intake of Nidanas deranges Pachaka Pitta by its increased Drava Guna (liquid) and Ushna Guna (hotness). Thus produced Ama leads to improper separation of Sarabhaga and Kittabhaga (essence portion and waste portion of food). As a result Dooshita Rasadhatu and Malaroopa Kapha get formed. Later the aggravated Pitta Ushma results in Vilayana (liquefying) of Malaroopa Kapha. Simultaneously the vitiated Pachaka Pitta results in vitiation of Bhrajaka Pitta. Because of Sthanavishesha, increased Kapha Dosha shows affinity towards Urdhajatru. The vitiated Vyana Vayu takes the aggravated Kapha to Shiras. As a result, vitiated Tarpaka Kapha in Shiras and vitiated Bhrajaka Pitta in Shirogata Twak leads to Prabhahani and manifests Vivarna Kesha. 


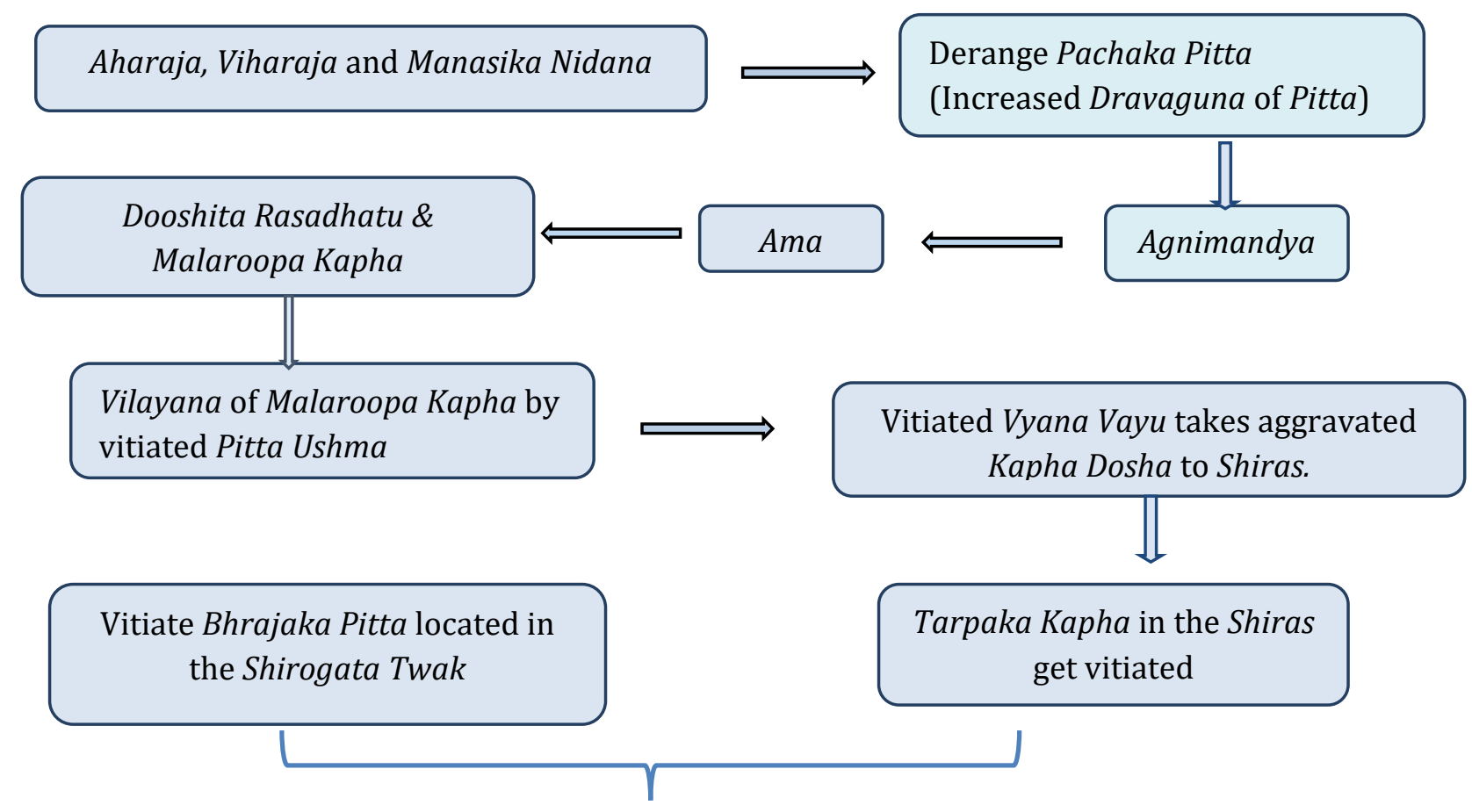

Kesha attains Prabhahani and Vivarnata

\section{Samprapthi Ghataka}

- Dosha: Tridosha

- Dushya
- Dhatu: Rasa
- Upadhatu: Kesha
- Mala: Kesha

- Agni:Jataragni, Rasadhatwagni

- Srotas: Rasavaha Srotas

- Udbahva Sthana: Amashaya

- Vyadhi Adhishtana: Shiras

- Vyakta Sthana: Kesha

- Rogamarga: Bahyarogamarga

\section{Clinical Features}

Discoloration of hair is the characteristic feature of Akala Palitam and the predominant Dosha, attributes coloration. Along with discolouration, texture of hair also gets affected. There are mainly four types of Akala Palitam, based on the predominance ofDosha.

Characteristics of each type of Akala Plaitam; ${ }^{[8]}$

- Vataja-Shyava, Sphutita, Khara, Ruksha, Jalaprabha

- Pittaja-Pitabha, Dahayukta

- Kaphaja-Sweta, Snigdha, Sthula, Vivridha

- Sannipataja-Sarva Lakshna

Likewise, variation in proportions of eumelanins (brown-black) and phaeomelanins (yellow-red) result in different types of hair colour.

\section{Figure 1: Samprapti}

Probably the variation in their proportions can be attributed to the predominant Dosha vitiation in Akala Palitam.

\section{Chikitsa (Treatment)}

Akala Palitam is a Rasapradoshaja Vikara, hence Shodhana (purification therapy) can be the main treatment. Apart from this, treatment principles consists of Shamana (palliative therapy) including both internal and external administration of medicines, Nidana Parivarjana (avoid consumption of causative factors), Rasayana (rejuvenating therapy) and following Pathya (wholesome food and regimes).

- Nidana Parivarjana- Avoid consumption of causative factors like excess daily intake of Lavana Rasa, avoid sedentary lifestyle as well as reduce over exertion and emotional stress.

- Shodhana- Based on the predominant Dosha involved in the disease manifestation. [9]

- Kaphapradhana Akala Palitam- Vamana

- Pittapradhana Akala Palitam- Virechana and Raktamokshana

- Vatapradhana Akala Palitam-Vasthi

- Nasya- for all types, because of its action in Urdhajatru Vikara (diseases affecting above the neck).

- Shamana- Includes both internal administration and external applications of medicines. 
Anupriya P.S, Arun Pratap, Lekshmi R, Arjun Chand C P. A Critical Evaluation on Akala Palitam

- Internal administration of medicated Ghrita (ghee)- Among the four types of Snehadravya (Ghrita, Majja, Vasa, Taila), Ghrita is considered as the best drug to pacify Pitta and Vata Dosha. It also corrects the Ksheena Kapha.

- External applications like Shiro Lepa and Shiro Abhyanga-

- Shiro Lepa (application of medicated paste on hair) with drugs having Kesharanjana (hair colouring) properties imparts black colour to hair.

- Shiro Abhyanga (application of oil on hair) is mentioned as a daily regimen. It helps in delaying ageing. So in order to manage and prevent Akala Palitam, it can be followed daily.

- Rasayana-

- Rasayana is beneficial for Varna as well as Prabha. [10]

o It is mainly indicated in early or in middle age.

- Administration after proper Shodhana helps to manage and prevent further progression of disease.

- Following Pathya- Follow food and regimens which pacifies Pittapradhana Tridosha.

\section{○ Pathya-}

\section{- Shashtika Shali, Dadima, Bhringaraja, Godugdha}

\section{- Shiro Abhyanga, Anutaila Nasya}

In contemporary medicine, treatment options for premature graying includes only drug therapy like nutritional supplements as well as hair coloring using different types of hair dyes. In Ayurveda, for Akala Palitam specific treatments are mentioned. So it can be managed in a better way after considering the predominant Dosha.

\section{CONCLUSION}

Akala Palitam manifests when there is Rasadhatudushti due to vitiated Pitta Dosha in association with other two Doshas. Hence Shodhana followed by Shamana can be adopted based on the predominant Dosha. After proper Shodhana, Rasayana is to be done which is beneficial for the management and prevention of Akala Palitam. In order to prevent

further progression of the disease it is essential to take wholesome food and regimens daily.

\section{REFERENCES}

1. Agnivesa. Revised by Charaka and Dridabala. Charaka Samhita with Ayurveda Deepika Commentary of Chakrapanidatta. Ed. Reprint 2018. New Delhi. Chaukambha Sanskrit Sansthan. 2018. p.350

2. Tobin DJ, Paus R. Graying: Gerantobiology of the hair follicle pigmentary unit. Exp Gerontol. 2001; 36: $29-54$

3. Panhard S, Lozano I, Loussouarn G. Greying of the human hair: A World wide survey, revisiting the 50 rule of thumb. Br J Dermatol.2012; 167: 865-73

4. Christopher Griffiths, Jonathan Barker, Tanya Bleiker, Robert Chalmers, Daniel Creamer, Rook. Textbook of Dermatology.9th ed. Oxford. Willey Blackwell. 2016. pg.no 89.68

5. Acharya Vagbhata, Ashtanga Hridaya translated by Prof.K.R Srikanta Murthy, Sutra Sthana $3^{\text {rd }}$ ed. Varanasi. Chaukambha Orientalia, 2000. pg.no169

6. Acharya Vagbhata, Ashtanga Hridaya translated by Prof.K.R Srikanta Murthy, Uttara Sthana. $3^{\text {rd }}$ ed. Varanasi. Chaukambha Orientalia,. 2000. pg223

7. Agnivesa. Revised by Charaka and Dridabala. Charaka Samhita with Ayurveda Deepika Commentary of Chakrapanidatta, Sareera Sthana. Reprint 2017. Varanasi. Chaukhamba Orientalia. pg 344

8. Acharya Vagbhata, Ashtanga Hridaya translated by Prof.K.R Srikanta Murthy, Uttara Sthana. $3^{\text {rd }}$ ed. Varanasi. Chaukambha Orientalia, 2000. pg223

9. Acharya Vagbhata, Astanga Samgraha translated by Prof.K.R Srikanta Murthy, Uttara Sthana, Reprint ed.2005.Varanasi. Chaukambha Orientalia. pg 242243

10. Agnivesa. Revised by Charaka and Dridabala. Charaka Samhita with Ayurveda Deepika Commentary of Chakrapanidatta, Chikitsa Sthana. Varanasi. Chaukambha Orientalia. Reprint 2017. pg.no 377

\section{Cite this article as:}

Anupriya P.S, Arun Pratap, Lekshmi R, Arjun Chand C P. A Critical Evaluation on Akala Palitam. International Journal of Ayurveda and Pharma Research. 2021;9(12):98-101.

https://doi.org/10.47070/ijapr.v9i12.2219

Source of support: Nil, Conflict of interest: None Declared

\section{*Address for correspondence} Dr. Anupriya P.S

Final Year PG Scholar, Department of Kayachikitsa, Pankajakasthuri Ayurveda Medical College \& PG Centre, Kattakkada, Thiruvananthapuram, Kerala, India.

Email: anusoman89@gmail.com Ph no: 9400686156

Disclaimer: IJAPR is solely owned by Mahadev Publications - dedicated to publish quality research, while every effort has been taken to verify the accuracy of the content published in our Journal. IJAPR cannot accept any responsibility or liability for the articles content which are published. The views expressed in articles by our contributing authors are not necessarily those of IJAPR editor or editorial board members. 